\title{
Hybrid wind-solar reliable solution for Turkey to meet electric demand
}

\author{
K. Dawood
}

\begin{abstract}
Energy is the most important part of life, it is essential for social and economic development. Turkey is importing more than half of the energy from other countries to produce electricity by thermal plants. Air pollution is also becoming quite a big problem for Turkey due to the thermal production of the energy. One of the most effective solution for air pollution is renewable energy because nowadays renewable energy is environment friendly. Turkey has many geographical location advantages one of them is renewable energy resources. Turkey has limited fossil fuel resources and due to this reason Turkey must shift more electricity production to the renewable energy resources. Renewable energy has less environment impacts as compare to the fossil fuels but still renewable energy sources are not reliable and competitive as compare to the fossil fuels. The present study deals with the advantages of Hybrid renewable energy systems (Solar and Wind energy) in Turkey.

Map of Turkey with high resources of solar-wind hybrid energy is also presented in this paper. Integration of Wind and solar energy into the Turkish energy will be one of the main tools in responding to the growing electricity demand because it will decrease the dependence of energy on single method. In addition, non-renewable energy is also compared with the renewable energy sources on the economical basis.
\end{abstract}

Index Terms - Renewable energy , Hybrid energy in Turkey, Solar energy, Wind Energy, Electricity generation in Turkey.

\section{INTRODUCTION}

$\mathrm{E}$ NERGY is one of the crucial inputs for socio-economic development. The rate at which energy is being consumed by a nation often reflects the level of prosperity that it could achieve [1]. Domestic oil and natural gas are not in sufficient quantity in the world to support the increasing demand of electricity. Air pollution is also becoming quite a big problem for the world. Thermal power production of the energy is also main reason of air pollution. One of the most effective solution for air pollution is renewable energy because nowadays renewable energy production is environment friendly. Renewable energy technologies can help countries to meet their policy goals for secure, reliable and affordable energy.

Turkey is importing more than half of the energy from other countries to produce electricity. Turkey has many geographical locational advantages, one of them is renewable energy resources. Turkey has limited fossil fuel resources and due to this reason Turkey must have to shift more electricity production to the renewable energy resources.

K. DAWOOD, is with Department of Electrical Engineering University of Kocaeli, Kocaeli, Turkey, (e-mail: kamransdaud@yahoo.com).

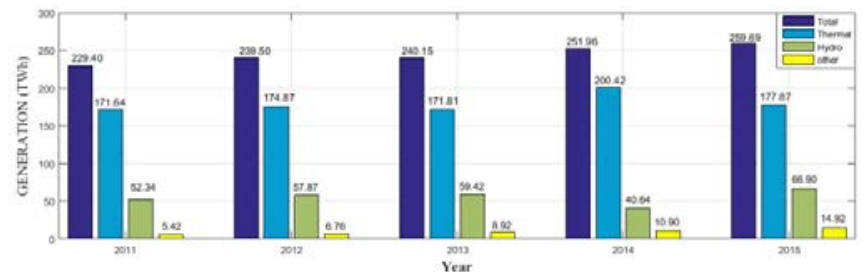

Fig.1. Generation of electric power since 2011 [2]

Figure 1 shows the generation of electricity in Turkey from 2011 to 2015. Last year, more than 68 percent of total electricity was generated by thermal power plants. Approximately 5 percent of the electricity was generated from renewable assets of Turkey, 26 percent of electricity generated through hydropower plants.

Turkey is one of the richest country in the world in terms of renewable resources. For geothermal energy Turkey is ranked first in Europe and seventh in the world. Installed capacity of wind energy in Turkey is increasing rapidly from 20MW in 2002 to 4503MW in 2015.

TABLE.1

TURKEy RENEWABLE ENERGY PLAN FOR 2023 [3]

\begin{tabular}{|l|l|l|l|l|l|l|}
\hline \multirow{2}{*}{$\begin{array}{l}\text { Renewable } \\
\text { energy } \\
\text { Technology }\end{array}$} & \multicolumn{3}{|l|}{\begin{tabular}{l}
\multicolumn{3}{l|}{$\begin{array}{l}\text { Installed Power Capacity } \\
\text { (MW) }\end{array}$} \\
\cline { 2 - 8 }
\end{tabular}} & \multicolumn{2}{l|}{ Electricity Generation (GWH) } \\
\hline Hydro & 22,289 & 34,000 & $53 \%$ & 59,420 & 91,800 & $54 \%$ \\
\hline Wind & 2,759 & 20,000 & $625 \%$ & 7,558 & 50,000 & $562 \%$ \\
\hline Geothermal & 310 & 1,000 & $223 \%$ & 1,364 & 5,100 & $274 \%$ \\
\hline Solar & 0 & 5,000 & - & 0 & 8,000 & - \\
\hline Biomass & 224 & 1,000 & $346 \%$ & 1,171 & 4,533 & $287 \%$ \\
\hline
\end{tabular}

\section{IMPORTANCE OF RENEWABLE ENERGY IN TURKEY}

In Turkey, electricity demand is increasing day by day and Turkey cannot rely on fossil fuel because Turkey is importing almost all of the fossil fuel from other countries. To fulfil the demand of energy Renewable energy is the best solution due to the insufficient resources of the non-renewable energy. Another big problem with the thermal projects is air pollution. Turkey is also concerned about the greenhouse gas (GHG) emissions which are rising rapidly: in 2010, they reached 403.5 Mt CO2-eq., a two-fold increase on 1990 levels [4]. Of this, $71 \%$ was emitted by the energy sector [5] to which electricity generation contributed $25 \%$ or 99 Mt CO2-eq [6].

As shown in Figure-2 fossil fuels like natural gas, coal and LNG are more than $50 \%$ of Turkey's installed capacity in 2015. Hydroelectric installed capacity in 2015 was 35.4\%. Installed capacity of wind power plant was 4503.2MW. Solar energy share is less as compare to others but still 248.8MW 
capacity was installed in 2015 which is $0.3 \%$ of total installed capacity.

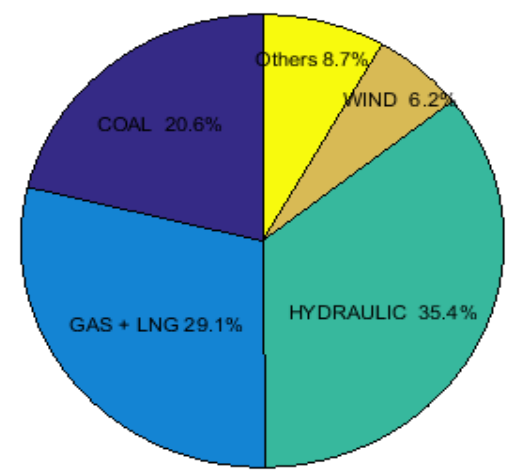

Fig.2. Installed Capacity of 2015 in Turkey [2]

Renewable energy can be divided into two main types. First where sun is the source; biomass, wind energy, hydro energy and solar energy is part of that energy. Tidal energy and geothermal energy is part of second type where sun is not source of the energy.

The renewable energy potential of Turkey is shown in Table 2. According to this table, Solar energy potential in Turkey is 977,000 (TWh/year) from which 6105 (TWh/year) is technically possible. However due to the high price of the solar energy only 305 (TWh/year) is economic potential but since few years price of the solar panels are decreasing rapidly and it will surely increase the economic potential of solar energy in Turkey. Wind energy technical potential is 290 TWh/year. Technical potential of hydraulic energy is 216 $\mathrm{TWh} /$ year and economical potential is 127.4 TWh/year.

TABLE 2.

RENEWABLE ENERGY SOURCES POTENTIAL IN TURKEY[7]

\begin{tabular}{|l|l|l|}
\hline Renewable energy Source & $\begin{array}{l}\text { Usage kind of } \\
\text { energy }\end{array}$ & Potential \\
\hline Solar energy & $\mathrm{kWh} / \mathrm{m}^{2}$ & 1,520 \\
\hline Hydraulic energy & TWh/year & 160 \\
\hline Wind energy & TWh/year & 48 \\
\hline Geotermal energy & MWt & 31,500 \\
\hline Biomass energy & MTEP & 8.6 \\
\hline Biogas & & $1.5-2$ \\
\hline
\end{tabular}

\section{ECONOMIC ANALYSIS OF POWER GENERATION FROM DIFFERENT SOURCES :}

Table-3 shows a 1MWh electricity levelized cost comparison between different types of energy sources. Renewable energy like hydroelectric, wind, geothermal and biomass energy are not too much expensive. The $1 \mathrm{MWh}$ production cost of wind energy is almost equal to the cost of $1 \mathrm{MWh}$ electricity produced from coal. However, there are many advantages of wind energy when it is compared with the conventional energy sources.
TABLE-3.[8]

PRODUCTION COST OF 1 MWH FROM DIFFERENT POWER SOURCES

\begin{tabular}{|l|l|l|l|}
\multicolumn{2}{|c}{ PowODUCTION COST OF 1 MWH FROM DIFFERENT POWER SOURCES } \\
\cline { 2 - 4 } & \multicolumn{3}{l|}{ Production cost (\$/MWh) } \\
\cline { 2 - 4 } & Minimum & Average & Maximum \\
\hline Conventional Coal & 87.1 & 95.1 & 119 \\
\hline Advanced Coal & 106.1 & 115.7 & 136.1 \\
\hline $\begin{array}{l}\text { Natural Gas Conventional } \\
\text { Combustion Turbine }\end{array}$ & 107.3 & 141.5 & 156.4 \\
\hline $\begin{array}{l}\text { Natural Gas Advanced } \\
\text { Combustion Turbine }\end{array}$ & 94.6 & 113.5 & 126.8 \\
\hline Advanced Nuclear & 91.8 & 95.2 & 101 \\
\hline Geothermal & 43.8 & 47.8 & 52.1 \\
\hline Biomass & 90 & 100.5 & 117.4 \\
\hline Wind & 65.6 & 73.6 & 81.6 \\
\hline Wind - Offshore & 169.5 & 196.9 & 269.8 \\
\hline Solar PV & 97.8 & 125.3 & 193.3 \\
\hline Solar Thermal & 174.4 & 239.7 & 382.5 \\
\hline Hydroelectric & 69.3 & 83.5 & 107.2 \\
\hline
\end{tabular}

Wind energy is a clean and environment friendly energy. Price of wave and solar PV is relatively high when it is compared with other methods.

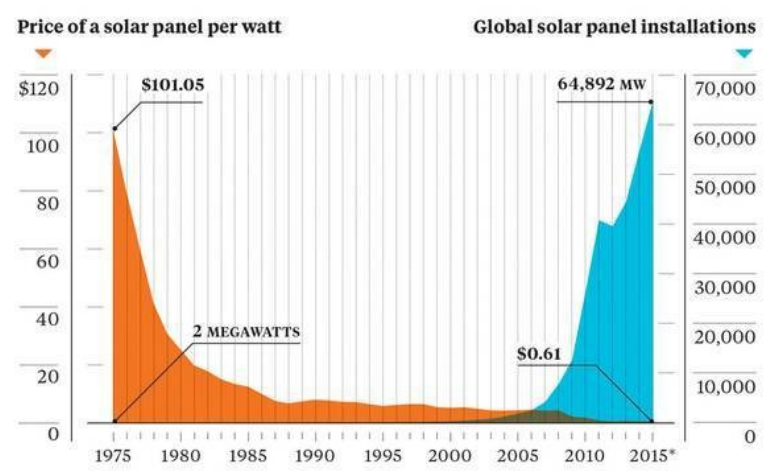

Fig.3. Price and Installation of solar panels [9]

Figure 3 shows the price and global installations of solar panel from 1975 to 2015. The falling cost of solar panel per watt caused the increment in the global installations of solar panels. The solar energy in the world is increasing rapidly due to the decreasing price of the solar panel. In 1975 price of a solar panel per watt was $101 \$$ which is decreased to the $0.61 \$$ in 2015.

\section{RENEWABLE ENERGY IN TURKEY}

\section{A. Hydroelectric Energy}

Hydroelectricity provide more than $16 \%$ of the world's electricity. Fossil fuels and natural gas potential is very low in Turkey, but potential of hydropower is very high in Turkey. Hydropower source is the second largest source to generate electricity in Turkey, coal is the first one. In developing country Hydroelectricity provide around $40 \%$ of the electric energy. Hydroelectric plants are more reliable and highly efficient. However, the dams and their large lake forms also have major environmental and social impacts [10,11].

Turkey has significant potential of renewable energy despite of this, the country's energy still depends on the fossil fuels, 
almost $65 \%$ of the total energy produced by fossil fuels in 2015. Hydropower is one of the most common renewable energy in the world and it also play vital role in the Turkey's energy production. The theoretical viable hydroelectric potential of the country has been estimated at $433 \mathrm{TWh} /$ year, nearly $1 \%$ of the total hydropower potential of the world $[12,13]$. But due to the technological limitations the hydroelectric potential almost decreases to the $50 \%$.

In 2015, the total installed capacity of hydropower in Turkey was $25868 \mathrm{MW}$, and total generated energy in 2015 from hydropower was 66903.2 GWh.

\section{B. Wind Energy}

Wind energy is one of the most environment friendly and costeffective solution for the generation of electricity. Wind power generation is increasing rapidly in the world. About $95 \%$ of wind capacity is now located in Asia (China and India), Europe and North America; and 90\% of new capacity was installed in those regions in 2015 (57.1 GW) [14].

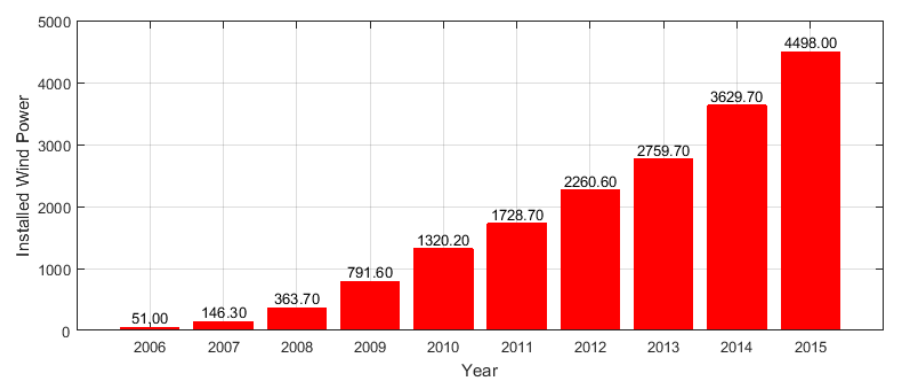

Fig.4. Wind Installed Capacity in Turkey [2]

Figure 4 shows the installed capacity of wind power plants since 2006. The installed capacity was $51 \mathrm{MW}$ in 2006 and it is increased to the 4498MW in 2015. Wind power in Turkey is increasing tremendously but still the desired level of the installed capacity is not reached because the wind potential is very high in Turkey. Despite this tremendous increase, the desired level of installed capacity is still not reached and a big share of the economic potential has still not been used.

The technical wind energy potential is estimated to be about $114 \mathrm{GW}$ of capacity in regions where the wind speed is higher than 7.0 meters above the ground at 50 meters' height [15].

\section{Solar Energy}

The major solar development in 2015 was the $48 \%$ increase in solar capacity in Asia, with 15 GW of new capacity installed in China and another $10 \mathrm{GW}$ in Japan. An increase of $8 \mathrm{GW}$ in North America also surpassed the level of new installations in Europe (7.6 GW) for the first time [14].

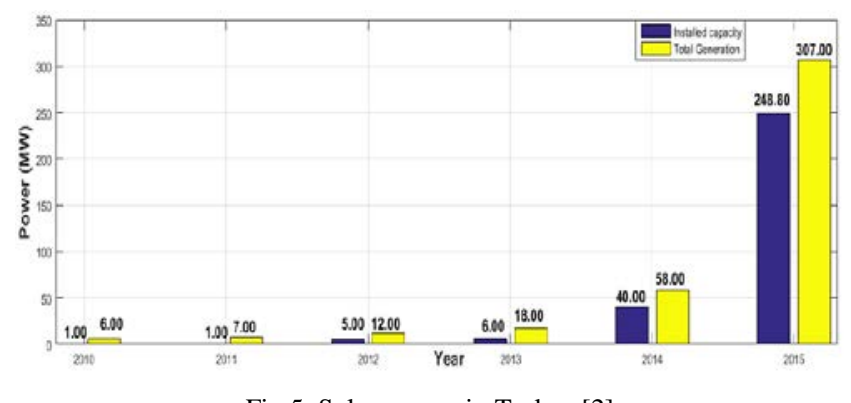

Fig.5. Solar energy in Turkey [2]
The installed capacity of solar energy in Turkey was just 40 in 2014 and it is increased to the 248.8MW in 2015 and total generation of solar energy in 2015 was $307 \mathrm{MW}$ in Turkey. Solar power in Turkey is increasing massively. Although solar panel prices are decreasing but still the generation cost of solar power is high as compare to the other power generation methods. Solar potential is very high in Turkey, especially in South Eastern Anatolia and Mediterranean regions solar energy potential is very high.

The government is also encouraging expansion and the utilization of solar energy for electricity generation. To stimulate investment in renewables, various incentive schemes have been introduced [16,17]. For example, renewable energy plants with an installed capacity of $500 \mathrm{~kW}$ or less are exempt from licensing obligations [18].

\section{Geothermal Energy}

Geothermal energy is thermal energy which is derived from the earth's internal heat. Use of the geothermal energy is not new and some countries have used geothermal energy for cooking and heating for thousands of years. In 1904 first time geothermal energy was used for electricity.

Geothermal power capacity is increased by about $600 \mathrm{MW}$ in 2015. Four countries (Italy, Mexico, Turkey and the United States of America) accounted for almost all of this increase. [14] Turkey is ranked seventh richest country in the world in geothermal potential. Turkey has significant potential of geothermal energy. In 2015, the total installed capacity of geothermal energy was 624MW. Turkey is one of the richest countries in the world in terms of geothermal energy resources, with the overall potential of $31.5 \mathrm{GW}$ [19].

\section{E. Biomass and Biofuel Energy}

Agricultural, forest, animal and other wastes are source of biomass and these can be used in the production of the energy. Biomass can be converted into biofuel as well. Biomass is generally used as a raw product in power turbines to generate steam. Biomass is one of the major resource from the renewable energy, as shown in Table-2 Turkey yearly biomass economical potential is 8.6 mtoe/year.

Turkey's domestic energy consumption accounts for about $37 \%$ of total energy consumption. Of this, about $52 \%$ is from biomass-based fuels [20]. The potential of important biomass energy sources and animal solid wastes of Turkey has been determined and the potential of these as a source of fuel in thermal generating systems to produce electricity and thermal energy has been studied [21,22]. The available agricultural and animal residues in Turkey have been estimated to be roughly equal to 22 - 27\% of energy consumption in Turkey [22]. The electrical production from usable biomass (about 17 Mtoe/year) has a net impact of $\$ 4.4$ billion in personal and corporate income and represents more than 160,000 jobs [23]. Generated electricity from biomass was 1171MW in 2013 and 4533MW is the target of Turkish government till 2023.

\section{HYBRID ENERGY}

Wind power generation is not increasing rapidly in Turkey as in the other parts of the world and main reason is variations in wind speed. Southern and eastern areas of the country have less wind potential as compare to the western areas of the country. Marmara and East Mediterranean area are one from the best wind potential in the Turkey. 
Integration of a large amount of renewable energy to the grid is still one of the biggest problem for renewable energy. Especially when the source of renewable energy is single. If integration is not well planned, it will lead to the large scale blackouts. Another efficient solution for that problem is hybrid renewable energy solution. Turkey has several geographical advantages; solar and wind energy is one from these advantages. Many areas of turkey have high wind potential and many areas have high solar potential. Some of the areas have high wind energy potential with high potential of solar energy as well. Fig. 6 highlighted areas with high potential of both solar and wind energy. Color representation is given in table 4. Çanakalle, Antakya, Mardin are the regions where both wind and solar energy resources are very high.

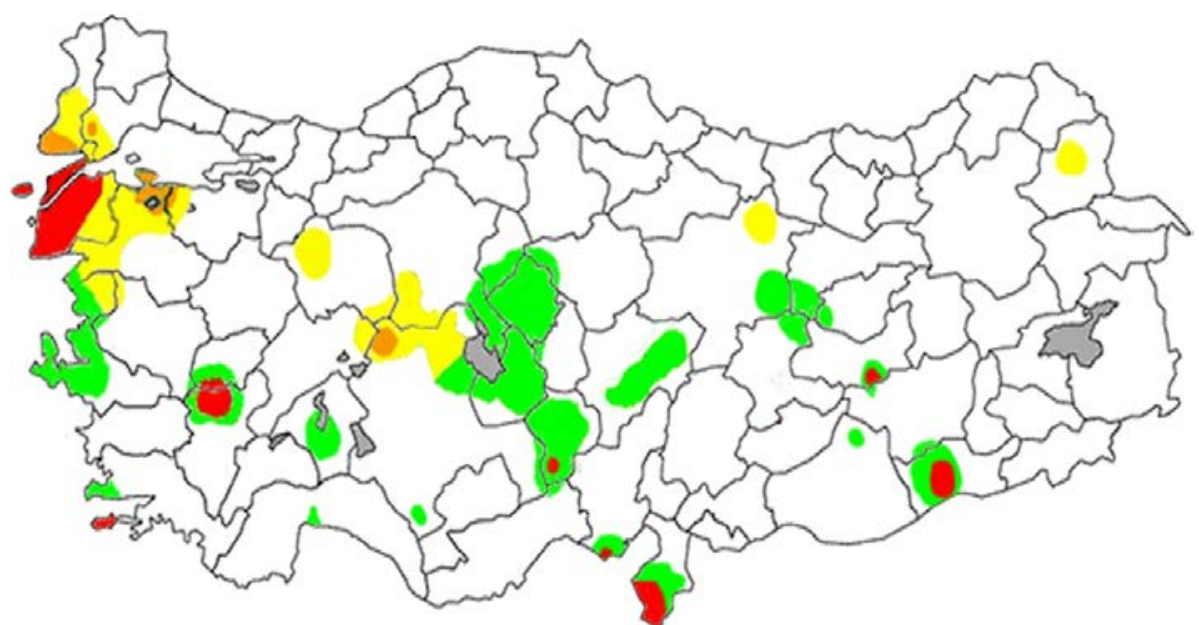

Fig. 6. Hybrid Energy in Turkey.

TABLE 4

Color representation of Figure 6

\begin{tabular}{|l|l|l|}
\hline Wind $[\mathbf{m} / \mathbf{s e c}]$ & $\begin{array}{l}\text { Global Horizontal Irradiation } \\
{\left[\text { Kwh } / \mathbf{m}^{2}\right]}\end{array}$ & Color \\
\hline wind $>3$ & irradiance $>1700$ & Red \\
\hline wind $>3$ & $1550<$ irradiance $>1700$ & Orange \\
\hline $2.4<$ wind $<3$ & irradiance $>1700$ & Green \\
\hline $2.4<$ wind $<3$ & $1550<$ irradiance $>1700$ & Yellow \\
\hline
\end{tabular}

Global Horizontal Irradiation is taken from [24] and it is average annual sum of 6 years from 2004 to 2010. Wind speed is taken from [25]. Hybrid renewable energy also has greater economic and environment returns when it is compared with stand-alone systems like geothermal, wind or solar systems. There are many advantages of wind- solar hybrid system. The system will be more reliable because there are two different power production systems are used. Dependence on single power system will be also minimize by using wind- solar hybrid system which will decrease the number of storage batteries. Another main advantage is that if one system is down for maintenance or repairing, system can rely on the other one, similar for the windy and sunny conditions.

\section{CONCLUSION}

Wind energy, solar energy and other types of renewable energy is important kind of sustainable energy. Demand of the electricity is increasing day by day and Turkey cannot rely on the fossil fuels because in Turkey these resources are limited. However, resources of renewable energy like hydroelectric energy, wind, solar, geothermal and biomass energy is much higher. Renewable energy like wind and solar energy have many advantages over other energy types but main disadvantage of wind and solar energy is reliability. This issue can be resolved by using hybrid energy. This paper also presents the map of Turkey where we can use Wind-solar hybrid plants. Hybrid energy make system more reliable, even with the no wind on hybrid system we can generate energy from solar energy.

\section{REFERENCES}

[1] Mathew S., Wind Energy Fundamentals, Resource Analysis and Economics, Springer, 2006

[2] Türkiye Elektrik İletim A.Ş., www.teias.gov.tr/

[3] National Renewable Energy Action Plan for Turkey, December 2014 http://www.eie.gov.tr/duyurular_haberler/document/National_Renewab le_Energy_Action_For_Turkey.PDF

[4] EEA, European Environment Agency, Greenhouse Gas Data Viewer: European Environment Agency, 2012 [Online]. Available from: http://www.eea.europa.eu/data-and-maps/data/dataviewers/greenhouse-gases-viewer.

[5] TUIK, National Greenhouse Gas Inventory Report, 1990-2010, Turkish Statistical Institute, Ankara, 2011.K. Elissa, “Title of paper if known,” unpublished.

[6] Future Camp, Baseline Emission Calculations. Verified Carbon Standard (VCS), Version 3, Turkey, Ankara, 2011.

[7] Usta R., Tükiye'nin yenilenebilir Enerji Stratejisi ve Politikalari, March 2015. http://www.tepav.org.tr/

[8] Levelized Cost and Levelized Avoided Cost of New Generation Resources in the Annual Energy Outlook 2015 US DOE Annual Energy Outlook 2015.

[9] Bloomberg http://www.treehugger.com/renewable-energy/strikingchart-showing-solar-power-will-take-over-world.html

[10] Kaygusuz K., Hydropower potential in Turkey. Energy Sources 1999;21:581-8.

[11] Kaygusuz, K. and Kaygusuz, A., "Geothermal Energy in Turkey: the Sustainable Future.” Renewable and Sustainable Energy Reviews, August 2004 http://www.inference.phy.cam.ac.uk/sustainable/refs/geothermal/sdartic le.pdf 
[12] Kilic F.C., Recent renewable energy developments, studies, incentives in Turkey, Energy Educ. Sci. Technol. Part A 28 (1) (2011) 37e54.

[13] Simsek H.A., Simsek N., Recent incentives for renewable energy in Turkey, Energy Policy 63 (0) (2013) 521e530.

[14] Baris K., Kucukali S., Availibility of renewable energy sources in Turkey: Current situation, potential, government policies and the EU perspective, Energy Policy 42 (0) (2012) 377e391.

[15] EMRA, RE: Data on Energy Potential of Turkey, Republic of Turkey Energy Market Regulatory Authority, Ankara, 2014 [Personel communication,15.06.2014].

[16] Demirbas A. Energy balance, energy sources, energy policy, future developments and energy investments in Turkey. Energy Convers Management, 2001, Vol.42, No.10, pp.1239-1258.

[17] Demirbas A. Biomass co-firing for coal-fired boilers. Energy Exploration \& Exploitation, 2003, Vol.21, No.3, pp.269-278.

[18] Balat M., The use of renewable energy sources for energy in Turkey and potential trends. Energy Exploration \& Exploitation, 2004 Vol.22, No.4, pp.241-257.

[19] Bascetincelik A, Karaca C, Ozturk HH, Kacıra M, Kaya D, Ekinci $\mathrm{K}$, et al. First progress report of exploitation of agricultural residues in Turkey. European Commission, LIFE third countries projects, 2004e2005. LIFE 03 TCY/TR/ 000061; 2005.

[20] GHI Solar Map 2016 Solargis http://solargis.com

[21] Meteorological Data Processing Department http://www.mgm.gov.tr/

\section{BIOGRAPHY}

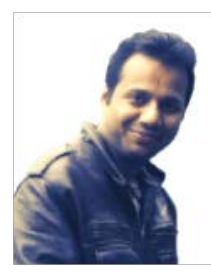

electric vehicles.
KAMRAN DAWOOD was born in Karachi, Pakistan in 1989. He received his B.E. Electrical engineering degree from Hamdard University, Karachi, Pakistan, in 2013. Hamdard University also awarded him gold medal for securing first position in Electrical Engineering. Currently he is doing M.Sc. degree in Electrical engineering from Kocaeli University, Izmit, Turkey. His current research interests involve renewable energy, power quality, smart grids and 